\title{
Bioefficacy of Rhizobacterial Isolates against Root Infecting Fungal Pathogens of Chickpea (Cicer arietinum L.)
}

\author{
Muhammad Inam-ul-Haq', Muhammad Ibrahim Tahir'1, Rifat Hayat ${ }^{2}$, Rabia Khalid², Muhammad Ashfaq', Muhammad Jamil ${ }^{3}$, Saadia Naseem $^{3}$ \\ and Zahid Ali ${ }^{3 *}$
}

${ }^{1}$ Department of Plant Pathology, Pir Mehr Ali Shah Arid Agriculture University, Rawalpindi, Pakistan

${ }^{2}$ Department of Soil Science and SWC, Pir Mehr Ali Shah Arid Agriculture University, Rawalpindi, Pakistan

${ }^{3}$ Department of Biosciences, COMSATS Institute of Information Technology, Park Road, Chak Shahzad, Islamabad, Pakistan

\begin{abstract}
Chickpea is considered to be food for the poor in Pakistan. Its yield is much lower than expected due to infestation of a number of fungal pathogens. The present study was designed to determine the effect of rhizobacterial isolates against fungal pathogens infecting chickpea roots. $\mathrm{RH}-31, \mathrm{RH}-32$ and $\mathrm{RH}-33$ were isolated from groundnut rhizosphere. Antifungal activities of these isolates were tested by seed treatment and soil application methods against three root fungal pathogens. Data on disease incidence, bio-control efficiency and root biomass was recorded. Phylogenetic analysis indicated that sequences of $\mathrm{RH}-31, \mathrm{RH}-32$ and $\mathrm{RH}-33$ showed $>99 \%$ identity with Paenibacillus illinoisensis, Bacillus subtilis, and Pseudomonas psychrotolerans respectively. RH-33 was effective against Fusarium oxysporum and Macrophomina phaseolina with highest levels of inhibition, whereas RH-32 inhibited Fusarium solani. However, RH-31 showed best activity against $F$. oxysporum. Disease incidence and bio-control efficiency revealed that all isolates reduced disease severity and increased overall plant biomass as compared to control treatment. Present findings show potential of bacterial isolates from rhizosphere of Pakistan. Application of selected rhizobacteria through seed treatment method might be a promising strategy to lower damage caused by root pathogens in chickpea. This could be efficient, economical, environment friendly and might serve as a biocontrol agent.
\end{abstract}

Keywords: Chickpea; Root diseases; Biocontrol; Fungal pathogens; Rhizobacteria

\section{Introduction}

Chickpea (Cicer arietinum L.) is a major source of human and animal food and the world's third most important pulse crop after beans (Phaseolus vulgaris L.) and peas (Pisum sativum L.) [1]. It is mostly grown under rain-fed conditions in arid and semi-arid areas around the world [2]. Pakistan is the third major chickpea producer in the world after India and Turkey [3]. During the year 2010, it was grown on about 1.05 million hectares with a total production of 0.50 million tons [4]. The average yield of chickpea was about $0.47 \mathrm{tha}^{-1}$ which is far lower than its potential yield of $4 \mathrm{tha}^{-1}$. A number of constraints such as infertile and marginal lands, drought or excessive moisture, increasing temperature, weeds and build up of pathogenic fungal pathogens are responsible for this yield gap in chickpea $[5,6]$.

There are about 30 diseases reported in chickpea. Three root diseases, i. e. Fusarium wilt, black root rot and dry root rot caused by Fusarium oxysporum, Fusarium solani and Macrophomina phaseolina, respectively, have greater significance. It was reported that Fusarium wilt caused $10-15 \%$ yield losses in chickpea [7]. While black root rot (another serious disease) caused $60-70 \%$ yield loss [8]. Dry root rot caused by $M$. phaseolina is endemic in temperate and tropical regions of the world with the capacity to infect over 500 different host crops [9].

Although many control measures have been developed to manage these diseases, the soil borne nature persistence in soil and a wide host range make control difficult. Using resistant varieties is one of the most effective methods. However, frequent changes in races of some pathogen are a great problem as this usually results in breakdown of host resistance. Other control measures involve cultural practices, biological and chemical control. Of these biological control has become as an alternative strategy for disease management, which is also ecology-conscious and environmentally friendly [10]. The rhizosphere provides the initial barrier for the roots against pathogen attack [11]. Plant growth-promoting rhizobacteria (PGPR) in the rhizosphere have the ability to improve plant growth by colonizing the root system and pre-empting the establishment of and suppressing deleterious microorganisms [12,13]. Rhizosphere microorganisms provide biocontrol through mechanisms such as production of antibiotics $[14,15]$, iron sequestering compounds, siderophores [16,17], extracellular hydrolytic enzymes [18], other secondary metabolites such as hydrogen cyanide (HCN) [19-22] and induced systemic resistance [23]. The individual as well as combined effects of some rhizobacterial isolates might be helpful to develop suitable strategies to reduce infection of some root pathogens in chickpea.

The objectives of this study were to evaluate the bioefficacy of single or mixture of two or three rhizobacterial isolates against the pathogens infecting chickpea roots and consequently their effects on growth and development of chickpea. Two application methods (seed treatment and soil application) of three rhizobacterial isolates as well as single or combined applications were studied.

\section{Materials and Methods}

\section{Isolation of F. oxysporum, F. solani and M. phaseolina}

Dilution technique was used for the isolation of fungal cultures as described earlier [24]. The fungal cultures of F. oxysporum, F. solani and $M$. phaseolina were obtained in composite forms, purified and

*Corresponding authors: Ali Z, Department of Biosciences, COMSATS Institute of Information Technology, Park Road, Chak Shahzad, Islamabad, Pakistan, Tel: +92-51-9247000; E-mail: zahidbiosciences@gmail.com

\section{Received May 08, 2014; Accepted August 28, 2014; Published May 08, 2015}

Citation: Inam-ul-Haq M, Tahir MI, Hayat R, Khalid R, Ashfaq M, et al. (2015) Bioefficacy of Rhizobacterial Isolates against Root Infecting Fungal Pathogens of Chickpea (Cicer arietinum L.). J Plant Pathol Microbiol S3: 011. doi:10.4172/21577471.S3-011

Copyright: @ 2015 Inam-ul-Haq M, et al. This is an open-access article distributed under the terms of the Creative Commons Attribution License, which permits unrestricted use, distribution, and reproduction in any medium, provided the original author and source are credited. 
identified [25]. Wet sieving and dilution technique [26] was used for isolation of Macrophomina phaseolina with its identification done according to keys described by Barnett and Hunter [27].

\section{Pathogenicity test of fungi}

Seeds of chickpea cultivar Bital-98 were surface sterilized in $70 \%$ ethanol (EtOH) (v/v) for 1 min followed by $1 \%$ sodium hypochlorite ( $\mathrm{NaOCl})$ for 5-10 min, with agitation as described by Ali et al. [28]. Fungal inocula were prepared according to a protocol described by Riker and Riker [29] with modifications by collecting mycelia on blotting paper to remove excess water and nutrients. The inoculum was prepared by $100 \mathrm{~g}$ wet mycelium and adding to $1 \mathrm{~L}$ distilled water. Ten milliliters of each fungal suspension was applied to each plant.

\section{Isolation of rhizobacteria}

The rhizospheric soil of groundnut plant was collected followed by isolation of rhizobacteria from the soil sample. $10 \mathrm{~g}$ of soil was added to $100 \mathrm{ml}$ sterile water in flasks and shaken on a rotary shaker at 150 rpm for $30 \mathrm{~min} .0 .1 \mathrm{ml}$ of the suspension from serial dilutions $\left(10^{-5}, 10^{-6}\right.$ and $10^{-7}$ ) was plated on Tryptic Soy Agar (TSA) media and incubated at $28^{\circ} \mathrm{C}$ for $48 \mathrm{~h}$. Resulting colonies were purified by streaking. Restreaking of the single colonies was performed as long as purified strains were obtained.

\section{In vitro evaluation of antagonistic rhizobacteria}

Antifungal activity of rhizobacterial isolates against $F$. oxysporum, M. phaseolina and F. solani was determined using the dual-culture plate method [30]. Individual PDA plates were inoculated with $F$. oxysporum, F. solani and M. phaseolina separately and challenged with individual rhizobacterial isolates. Rhizobacteria were inoculated in the center of the petri plate and the fungi were inoculated at a minimum separation of $1 \mathrm{~cm}$ between fungus and bacteria. The test was performed with three replications per treatment. The plates were incubated at 25 $\pm 2^{\circ} \mathrm{C}$. The diameter of inhibition zones between the rhizobacteria and fungal pathogens was recorded in centimeters $72 \mathrm{hrs}$ post incubation.

\section{Identification of rhizobacteria by $16 \mathrm{~S}$ rRNA gene sequencing}

DNA extraction was performed as described by Ali et al. [31]. The amplification of the $16 \mathrm{~S}$ rRNA gene was carried out by using universal primers (9F: 5'AGTTTGATCCTGGCTCAG-3'; 1510R and $5^{\prime}$-GGCTACCTTGTTACGA-3') as described by Katsivela et al. [32]. The amplification program for the full-length $16 \mathrm{~S}$ rRNA gene consisted of an initial denaturation at $94^{\circ} \mathrm{C}$ for $2 \mathrm{~min}$, followed by 30 cycles of denaturation at $94^{\circ} \mathrm{C}$ for $2 \mathrm{~min}$, primer annealing at $55^{\circ} \mathrm{C}$ for $1 \mathrm{~min}$ and primer extension at $72^{\circ} \mathrm{C}$ for $2 \mathrm{~min}$, followed by a final extension at $72^{\circ} \mathrm{C}$ for $10 \mathrm{~min}$ in a thermocycler (SIGMA Laborzentrifugen $\mathrm{GmbH}$, Germany). Amplified PCR products of the $16 \mathrm{~S}$ ribosomal gene were separated on $1 \%$ agarose gel in $0.5 \times \mathrm{TE}$ (Tris-EDTA) buffer containing $2 \mu \mathrm{L}$ ethidium bromide $\left(20 \mathrm{mg} \mathrm{mL}^{-1}\right)$. The $\lambda$ HindIII ladder was used as a size marker. The purified PCR products were sent to MACROGEN (Seoul, Korea) for sequencing. Phylogenetic analyses were performed using bioinformatics software MEGA-5 [33]. CLUSTAL X and BioEdit were used for sequence alignment and comparisons, respectively. The DNA accession numbers of each strain were obtained from the DNA Data Bank of Japan (DDBJ). The phylogenetic relationships of RH31, RH-32 and RH-33 strains were performed with its closely related taxa on the basis of the16S rRNA gene sequence. Cluster analysis was performed having bootstrap value 500 using MEGA- 5 software. For $\mathrm{RH}-31$, the tree was constructed on the basis of the neighbor-joining method using Thermobacillus xylanilyticus (AJ005795) as an out group.
For RH-32, the tree was constructed on the basis of the neighborjoining method using Bacillus cereus (AE016877) as an out group and for RH-33, the tree was constructed on the basis of the neighbor-joining method using Acinetobacter calcoaceticus (Z93434) as an out group.

\section{Colony forming units (cfu) $\mathrm{mL}^{-1}$ in suspension}

After making the suspension of biological antagonists, population of bacteria were counted by dilution plate method as described earlier [20]. One mL suspension was poured on Nutrient Agar (NA) medium and incubated at $28{ }^{\circ} \mathrm{C}$ for 3 to 7 days. Bacteria growing on NA plates were counted and multiplied by the dilution factor which gave $\mathrm{cfu} / \mathrm{mL}$ of bacteria.

\section{Colony forming unit (cfu) per seed}

Ten seeds were treated with suspension of microbial antagonists. Following treatment these seeds were transferred to test tubes containing $10 \mathrm{~mL}$ sterilized water. The test tubes were vigorously shaken and dilution series made as described by Haq et al. [24]. A serial dilution and plating method was used for determining the bacterial colony forming units of bacteria which was calculated by using the following formula:

cfu of bacteria per seed $=$ No. of colonies of bacteria $\times$ dilution factor

\section{Seed treatment and soil application of rhizobacteria}

Chickpea seeds were surface sterilized with $6 \%$ sodium hypochlorite ( $\mathrm{NaOCl})$ for 5-10 min, with agitation as described by Ali et al. [28] for both lab and greenhouse studies. The seeds were sown in sterilized soil with a 3:1:1 composition of soil:sand:compost. Two methods of rhizobacterial application seed treatment vs soil application were adopted. For seed treatment the seeds were soaked in King's B broth medium containing bacterial population $1 \times 10^{7} \mathrm{cfu} \mathrm{mL}^{-1}$ for 30 minutes and then dried shortly before seeding. For soil application method, 10 $\mathrm{mL}$ of bacterial suspension $\left(1 \times 10^{7} \mathrm{cfu} \mathrm{mL}^{-1}\right)$ was added, with the help of test tube, in the pot soil prior to seeding. Following seed setting, $5 \mathrm{~mL}$ inoculum of each fungal culture $\left(2 \times 10^{6}\right.$ propagules $\left./ \mathrm{mL}\right)$ was applied in the root zone of chickpea plant and plants were kept at $28 \pm 2^{\circ} \mathrm{C}$ for 40 days. Treatments of antagonistic rhizobacterial isolates were applied individually and in combination both in laboratory and greenhouse studies at the time of sowing, 1, 2 and 3 weeks after seeding. The control was treated with distilled water. The experiment was performed in a randomized complete design (RCD) with three replications per treatment.

\section{Data collection}

The data of disease incidence (DI), biocontrol efficiency (BCE), and dry weight of root (DWR) was recorded every week till $4^{\text {th }}$ week of the study period.

Biological control efficacy (BCE) was calculated using the following formula [34]:

BCE $(\%)=[$ D.I. (c) - D.I. (t)/D.I.(c)] x 100

D.I. (c)=Disease incidence on control

D.I. $(\mathrm{t})=$ Disease incidence on treatment group

Disease incidence (DI) was calculated using the following formula [34]:

DI (\%)=[Number of wilted plants/Total number of plants] $x 100$ 
Citation: Inam-ul-Haq M, Tahir MI, Hayat R, Khalid R, Ashfaq M, et al. (2015) Bioefficacy of Rhizobacterial Isolates against Root Infecting Fungal Pathogens of Chickpea (Cicer arietinum L.). J Plant Pathol Microbiol S3: 011. doi:10.4172/2157-7471.S3-011

Page 3 of 8

\section{Statistical analysis}

Standard procedure was adopted for recording data on disease incidence and plant growth and development. Data collected were statistically analysed by using Genstat 9.2 (VSN international Ltd, UK) statistical package for ANOVA on disease incidence, biological control efficiency and root dry weight, followed by a Posthoc LSD test for comparison of means. Regression analysis was done to determine the relationship between various treatments and disease incidence.

\section{Results}

\section{Phylogenetic analysis}

The rooted trees showing the phylogenetic relationship of the isolates with closely related taxa on the basis of $16 \mathrm{~S}$ rRNA gene sequence are shown (Figure 1a-1c). All three rhizobacterial isolates showed $>99 \%$ sequence identity to the closely related neighbors. Strain RH-31 showed > 99\% similarity to Paenibacillus illinoisensis, $\mathrm{RH}-32$
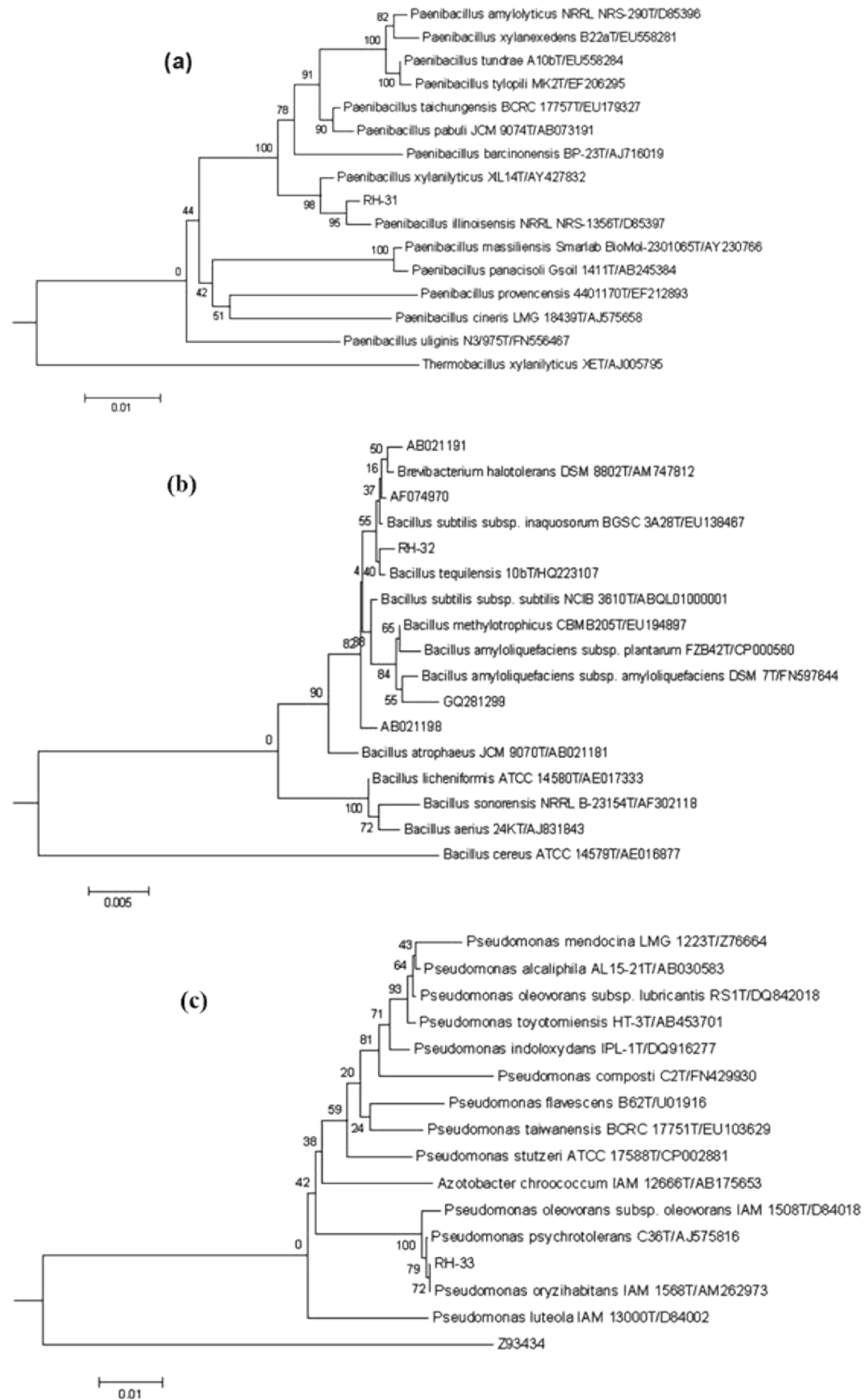

Figure 1: Rooted tree showing the phylogenetic relationships of RH-31, RH-32 and RH-33 with its closely related taxa on the basis of $16 \mathrm{~S}$ rRNA gene sequence. The cluster analysis was performed having bootstrap value 500 using MEGA- 5 software (a) RH-31; the tree was constructed on the basis of the neighbor-joining method using Thermobacillus xylanilyticus (AJ005795) as an out group. (b) $\mathrm{RH}-32$; the tree was constructed on the basis of the neighbor-joining method using Bacillus cereus (AE016877) as an out group. (c) RH-33; the tree was constructed on the basis of the neighbor-joining method using Acinetobacter calcoaceticus (Z93434) as an out group. 
Citation: Inam-ul-Haq M, Tahir MI, Hayat R, Khalid R, Ashfaq M, et al. (2015) Bioefficacy of Rhizobacterial Isolates against Root Infecting Fungal Pathogens of Chickpea (Cicer arietinum L.). J Plant Pathol Microbiol S3: 011. doi:10.4172/2157-7471.S3-011

showed $>99 \%$ similarity to Bacillus subtilis and strain RH-33 showed > 99\% similarity to Pseudomonas psychrotolerans. The Gene Bank/ DDBJ accession numbers for the 16S rRNA gene sequences for strains RH-31, RH-32 and RH-33 are AB773828, AB773829 and AB773830, respectively.

\section{In vitro evaluation of rhizobacteria}

The rhizobacterial isolates showed strong antagonistic activities against the three fungal pathogens tested in this study (Table 1). The isolate $\mathrm{RH}-33$ showed highest levels of inhibition against $M$. phaseolina $(1.65 \mathrm{~cm})$ whereas the diameter of inhibition zones against $F$. oxysporum and F. solani was $1.32 \mathrm{~cm}$ and $1.28 \mathrm{~cm}$, respectively (Figure 2). The isolate RH-32 was found best against $F$. solani with a $1.50 \mathrm{~cm}$ zone of inhibition as compared to $F$. oxysporum and M. phaseolina $(1.17 \mathrm{~cm}$ and $1.00 \mathrm{~cm}$ zone of inhibition, respectively). However, the isolate RH-31 had at $1.19 \mathrm{~cm}$; a zone against F. oxysporum (Table 1). The pathogens isolated from disease samples were re-isolated in the pathogenicity test which confirmed the pathogen to be the actual cause of the disease. The pathogens were pathogenic that incited disease in as evident from the symptoms that appeared on the roots.

\section{Evaluation of rhizobacteria against fungal pathogens}

Disease incidence (DI): The application of bacterial isolates showed a trend in reducing disease incidence (DI) from $1^{\text {st }}$ week to $4^{\text {th }}$ week of study as compared to control treatment both in laboratory and green house experiments (Table 2). The combined application of the three isolates showed more suppression of pathogens as compared to their sole application. In laboratory study, DI was $0.1-0.5 \%$ in mixed inoculation treatment as compared to control (12-47\% DI). Strain RH33 was less effective as compared to other strains or their combined applications. However, in the greenhouse study mixed application of the isolates appeared most effective against the pathogens (0.1-14\% DI) where $15-54 \%$ DI was observed in control plants. Both seed treatment and soil applied application methods showed significantly affected DI. A negative relationship was found between DI and treatments (Figure $3)$.

Biocontrol efficiency: The isolates $\mathrm{RH}-31, \mathrm{RH}-32$ and $\mathrm{RH}-33$ showed significant effects for biocontrol efficiency starting from $1^{\text {st }}$ week to $4^{\text {th }}$ week of study (Table 2). Both in the lab and green house experiments, the combined application of the isolates was more promising as compare to their sole application. In laboratory study, the biocontrol efficiency was $88-99 \%$ in mixed inoculation treatment as compared to control treatment (Table 2). The sole application of bacterial strain RH-33 proved comparatively less efficient (28-36\%). Both seed treatment and soil applied application methods resulted in highly significant effect on control efficiency (Table 2). In the greenhouse study, combination of three isolates performed best with maximum control efficiency (74-99\%) over control treatment (Table 2). However the sole application of all three bacterial strains appeared comparatively less efficient (26-44\%) as compared to their mixed application. The pathogens were significantly affected by bacterial isolates. The treatment $\mathrm{T}_{8}(\mathrm{RH}-33+\mathrm{RH}-32+\mathrm{RH}-31)$ expressed the best control against the pathogens with $100 \%$ efficacy while $\mathrm{T}_{2}, \mathrm{~T}_{3}$ and $\mathrm{T}_{4}$ (sole application of RH-31, RH-32, RH-33) exhibited less efficiency against fungal pathogens.

Root dry weight: The combined applications of bacterial isolates showed better effect on root dry weight of chickpea plants starting from $1^{\text {st }}$ week up to $4^{\text {th }}$ week of study over control treatment (Table 3). The combined application of three isolates led to maximum root growth and dry weight both in lab scale (0.04-0.2 g) and the greenhouse study (0.03-0.12 g) (Table 3). The sole application of all three bacterial strains showed comparatively less root growth $0.03-0.1 \mathrm{~g}$ in in vitro study and $0.02-0.09 \mathrm{~g}$ in green house study as compared to their combined application. Both seed treatment and soil applied application methods influenced root dry weight significantly (Table 3 ). The pathogens

\begin{tabular}{|c|c|c|c|}
\hline \multirow{2}{*}{ Isolates } & \multicolumn{2}{|c|}{ Inhibition zone (cm) } \\
\cline { 2 - 4 } & F. oxysporum & \multicolumn{1}{|c|}{ F. solani } \\
\hline Control & 0 & $1.28 \pm 0.11$ \\
\hline RH-33 & $1.32^{\mathrm{a}} \pm 0.12$ & $1.50 \pm 0.04$ \\
\hline RH-31 & $1.17 \pm 0.12$ & $1.65 \pm 0.16$ \\
\hline
\end{tabular}

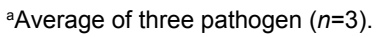

$\mathrm{RH}-33$ strain showed highest activity for zone of inhibition against the pathogen $M$. phaseolina i.e. $1.65 \mathrm{~cm}$

Control=No rhizobacterial inoculation

$\mathrm{RH}-31=$ Paenibacillus illinoisensis.

$\mathrm{RH}-32=$ Bacillus subtilis.

$\mathrm{RH}-33=$ Pseudomonas psychrotolerans.

Table 1: Antagonistic activity of rhizobacterial isolates in terms of inhibition zone caused by fungal pathogens (Fusarium oxysporum, F. solani and Macrophomina phaseolina).
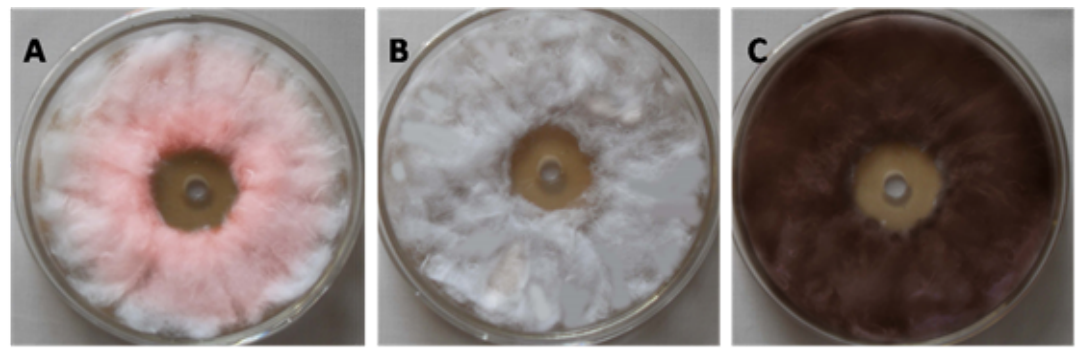

Figure 2: Antagonistic activity of rhizobacterial isolates $\mathrm{RH}-33$ in terms of inhibition zone (cm) caused by fungal pathogens Fusarium oxysporum, $F$. solani and $M$. phaseolina. A. RH-31 vs. F. oxysporum, B. RH-32 vs. F. solani. C. RH-33 vs. Macrophomina phaseolina. 
Citation: Inam-ul-Haq M, Tahir MI, Hayat R, Khalid R, Ashfaq M, et al. (2015) Bioefficacy of Rhizobacterial Isolates against Root Infecting Fungal Pathogens of Chickpea (Cicer arietinum L.). J Plant Pathol Microbiol S3: 011. doi:10.4172/2157-7471.S3-011

Page 5 of 8

\begin{tabular}{|c|c|c|c|c|c|c|c|c|}
\hline \multirow[t]{3}{*}{ S.O.V } & \multicolumn{4}{|c|}{ Laboratory study } & \multicolumn{4}{|c|}{ Greenhouse study } \\
\hline & \multicolumn{2}{|c|}{ Disease incidence (\%) } & \multicolumn{2}{|c|}{ Bio control efficiency (\%) } & \multicolumn{2}{|c|}{ Disease incidence (\%) } & \multicolumn{2}{|c|}{ Bio control efficiency (\%) } \\
\hline & $1^{\text {st }}$ week & $4^{\text {th }}$ Week & $1^{\text {st }}$ week & $4^{\text {th }}$ Week & $1^{\text {st }}$ week & $4^{\text {th }}$ Week & $1^{\text {st }}$ week & $4^{\text {th }}$ Week \\
\hline $\mathrm{T}_{1}=$ Control & $12.1^{\star} \mathrm{a}^{1}$ & $43.7 \mathrm{a}$ & $0 \mathrm{f}$ & $0 \mathrm{f}$ & $15 \mathrm{a}$ & $54 \mathrm{a}$ & $0 \mathrm{e}$ & $0 \mathrm{~d}$ \\
\hline $\mathrm{T} 2=\mathrm{RH}-33$ & $7.8 \mathrm{~b}$ & $31.4 \mathrm{~b}$ & $36 \mathrm{e}$ & $28 \mathrm{e}$ & $8 \mathrm{~b}$ & $36 \mathrm{~b}$ & $44 \mathrm{~cd}$ & $32 \mathrm{c}$ \\
\hline $\mathrm{T} 3=\mathrm{RH}-32$ & $7.7 \mathrm{~b}$ & $29.7 \mathrm{~b}$ & 36 e & $32 \mathrm{e}$ & $9 \mathrm{~b}$ & $39 \mathrm{~b}$ & $35 d$ & $26 \mathrm{c}$ \\
\hline $\mathrm{T} 4=\mathrm{RH}-31$ & $6.9 \mathrm{~b}$ & 29.1 bc & $44 \mathrm{~d}$ & 34 e & $9 \mathrm{~b}$ & $36 \mathrm{~b}$ & $37 \mathrm{~d}$ & $30 \mathrm{c}$ \\
\hline $\mathrm{T} 5=\mathrm{RH}-33+\mathrm{RH}-32$ & $2.7 \mathrm{c}$ & $15.7 \mathrm{c}$ & $79 c$ & $65 d$ & $5 \mathrm{c}$ & $25 c$ & $68 c$ & 52 bc \\
\hline $\mathrm{T} 6=\mathrm{RH}-33+\mathrm{RH}-31$ & $1.2 \mathrm{c}$ & $12.5 \mathrm{~d}$ & $91 \mathrm{~b}$ & $72 \mathrm{c}$ & $3 d$ & $22 \mathrm{c}$ & $79 \mathrm{~b}$ & $58 \mathrm{~b}$ \\
\hline $\mathrm{T} 7=\mathrm{RH}-32+\mathrm{RH}-31$ & $0.6 \mathrm{~cd}$ & $9.0 \mathrm{e}$ & $95 \mathrm{a}$ & $80 \mathrm{~b}$ & $3 d$ & $21 \mathrm{~cd}$ & $81 \mathrm{~b}$ & $58 \mathrm{~b}$ \\
\hline $\mathrm{T} 8=\mathrm{RH}-33+\mathrm{RH}-32+\mathrm{RH}-31$ & $0.1 \mathrm{~d}$ & $5.6 \mathrm{f}$ & 99 a & $88 \mathrm{a}$ & $0.1 \mathrm{e}$ & $14 \mathrm{~d}$ & 99 a & $74 \mathrm{a}$ \\
\hline Treatments $(T)$ & $* * *$ & $* \star \star$ & $\star * *$ & $* * *$ & $* * *$ & $\star * \star$ & $* \star \star$ & $\star * *$ \\
\hline Application methods (AM) & $* * *$ & $* * *$ & $* *$ & $* * *$ & * & $* *$ & NS & NS \\
\hline Pathogen & $* * *$ & $* * *$ & $* * *$ & * & $* * *$ & $* * *$ & $* *$ & $* *$ \\
\hline Treatments X AM & * & NS & NS & ** & NS & NS & NS & NS \\
\hline Treatments X Pathogen & $* * *$ & $* *$ & * & NS & $* * *$ & NS & * & NS \\
\hline Pathogen X AM & NS & NS & NS & NS & NS & NS & NS & NS \\
\hline S.E. Treatment means $(P)$ & 0.4 & 0.9 & 3.45 & 2.3 & 0.47 & 1.7 & 3.9 & 3.0 \\
\hline LSD Treatment means (5\%) & 0.7 & 1.9 & 6.8 & 4.6 & 0.93 & 3.3 & 7.8 & 6.0 \\
\hline
\end{tabular}

Average of three pathogen ( $n=3$ ). Means not sharing a common letter differ significantly at $P=0.05$; NSNon-significant; LSD Least significant differences of means at $P=0.05$ by ANOVA test. ${ }^{*} P<0.05 .{ }^{* *} P<0.01$. ${ }^{* * *} P<0.001$. ${ }^{\text {S.E. }}$ Standard error of treatment means.

Pathogens=Fusarium solani, Fusarium oxysporum and Macrophomina phaseolina.

$\mathrm{RH}-31=$ Paenibacillus illinoisensis.

$\mathrm{RH}-32=$ Bacillus subtilis.

$\mathrm{RH}-33=P$ seudomonas psychrotolerans.

Table 2: Disease incidence and biological control efficiency as affected by various types of rhizobacterial isolates in individual and combined application method on the root pathogens in chickpea in terms of different times (days) in Laboratory and Greenhouse study.

a) Lab study
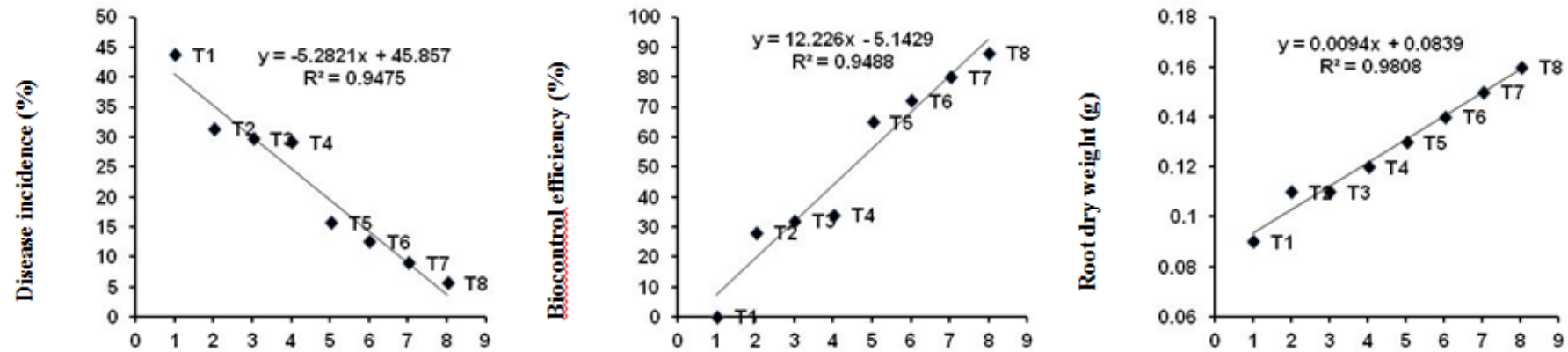

b) Green house study

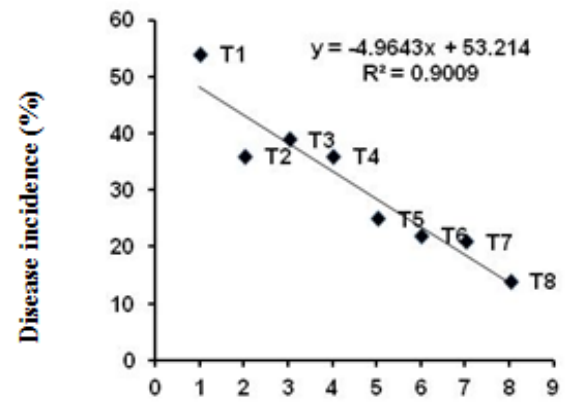

Treatments

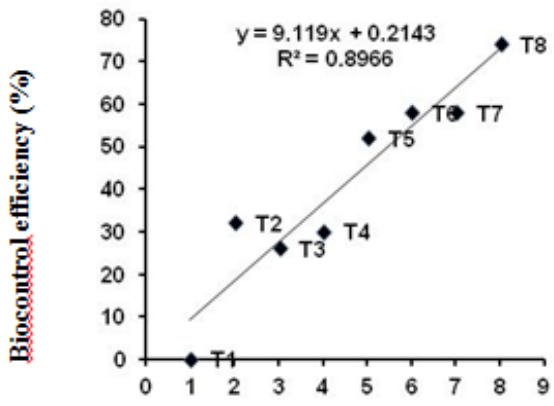

Treatments

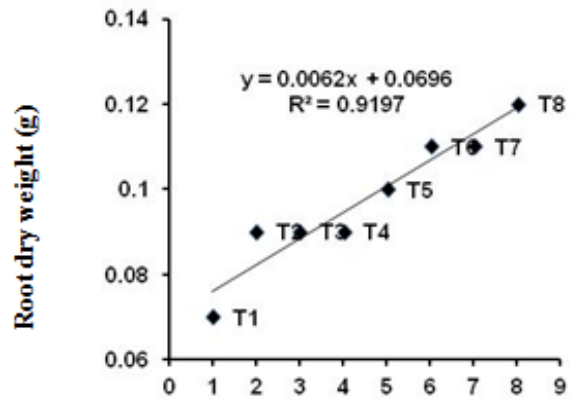

Treatments

Figure 3: Relationship between treatments and disease incidence, bio-control efficiency and root dry weight. The relationship was determined using average of three pathogens. $\mathrm{T}_{1}=$ Control, $\mathrm{T}_{2}=\mathrm{RH}-33, \mathrm{~T}_{3}=\mathrm{RH}-32, \mathrm{~T}_{4}=\mathrm{RH}-31, \mathrm{~T}_{5}=\mathrm{RH}-33+\mathrm{RH}-32, \mathrm{~T}_{6}=\mathrm{RH}-33+\mathrm{RH}-31, \mathrm{~T}_{7}=\mathrm{RH}-32+\mathrm{RH}-31, \mathrm{~T}_{8}=\mathrm{RH}-33+\mathrm{RH}-32+\mathrm{RH}-31(\mathrm{RH}-33=P$ seudomonas psychrotolerans; $\mathrm{RH}-32=$ Bacillus subtilis; $\mathrm{RH}-31=$ Paenibacillus illinoisensis). 


\begin{tabular}{|l|c|c|c|c|}
\hline S.O.V & \multicolumn{2}{|c|}{ Laboratory study } & \multicolumn{2}{c|}{ Greenhouse study } \\
\hline & $1^{\text {st }}$ week & $4^{\text {th }}$ Week & $1^{\text {st }}$ week & $4^{\text {th }}$ Week \\
\hline $\mathrm{T}_{1}=$ Control & $0.021^{\mathrm{a}}$ & 0.09 & 0.019 & 0.07 \\
\hline $\mathrm{T} 2=\mathrm{RH}-33$ & 0.027 & 0.11 & 0.025 & 0.09 \\
\hline $\mathrm{T} 3=\mathrm{RH}-32$ & 0.028 & 0.11 & 0.023 & 0.09 \\
\hline $\mathrm{T} 4=\mathrm{RH}-31$ & 0.027 & 0.12 & 0.026 & 0.09 \\
\hline T5=RH-33+RH-32 & 0.031 & 0.13 & 0.029 & 0.10 \\
\hline T6=RH-33+RH-31 & 0.033 & 0.14 & 0.031 & 0.11 \\
\hline T7=RH-32+RH-31 & 0.034 & 0.15 & 0.031 & 0.11 \\
\hline T8=RH-33+RH-32+RH-31 & 0.039 & 0.16 & 0.034 & 0.12 \\
\hline Treatments (T) & $* * *$ & $* * *$ & $* * *$ & $* * *$ \\
\hline Application methods (AM) & $* * *$ & $* *$ & NS & $* * *$ \\
\hline Pathogen & $* * *$ & $* *$ & $* * *$ & $* * *$ \\
\hline Treatments X AM & $\mathrm{NS}$ & $\mathrm{NS}$ & $\mathrm{NS}$ & $\mathrm{NS}$ \\
\hline Treatments X Pathogen & $\mathrm{NS}$ & $*$ & $\mathrm{NS}$ & $*$ \\
\hline Pathogen X AM & $* * *$ & $\mathrm{NS}$ & $\mathrm{NS}$ & $\mathrm{NS}$ \\
\hline S.E. Treatment means $(P)$ & 0.001 & 0.002 & 0.0009 & 0.002 \\
\hline LSD Treatment means $(5 \%)$ & 0.002 & 0.005 & 0.0015 & 0.004 \\
\hline
\end{tabular}

the present study where the isolate $\mathrm{RH}-33$ was found to be an effective biocontrol agent as it suppressed not only the charcoal rot pathogen i.e. M. phaseolina but also F. solani, F. oxysporum. In addition, it also increased the root fresh and dry weight of treated plants (Table 3). The antifungal activity of these isolates may be associated with production of antifungal metabolites [42]. The absorption of these antifungal metabolites by chickpea roots may be another reason for the reduced disease levels and increased plant growth [44].

In addition to Pseudomonas species, both Bacillus and Paenibacillus spp. express antagonistic activities by suppressing the pathogens under in vitro and in vivo conditions [36-38]. P. illinoisensis has been investigated against various soil borne pathogens like Phytophthora capsici and Rhizoctonia solani and results have to be proved it a potential antagonist. Paenibacillus illinoisensis has strong chitinolytic activity and efficient against Rhizoctonia solani [45]. The bacterium suppressed the symptom of damping-off in cucumber seedlings caused by $R$. solani, in a greenhouse trial. Three major chitinase bands with chitinolytic activity and release of $\mathrm{N}$-acetyl-d-glucosamine were also found to be associated to $P$. illinoisensis [46]. In our study, $P$. illinoisensis have shown promising results in controlling the fungal root pathogens of chickpea with variable results against each pathogen. Similarly Bacillus subtilis is well known as efficient gram positive biocontrol bacteria as well as plant growth promoting agents due to production of growth hormones (Indole Acetic Acid) [47,48]. In this study B. subtilis showed suppressive ability as a biocontrol agent. Seed treatment method was found more promising as compared to the soil application method. The results of our study also confirmed the findings of Karimi et al. [49] that seed treatment is more reliable than the soil application method. All three isolates RH-31, RH-32 and RH-33 showed their ability to promote the growth of chickpea plants in the presence of the pathogen. These results showed that RH-33 ( $P$. psychrotolerans) could be used as an effective biocontrol agent against chickpea diseases and potential plant growth promoter. The combined application of the isolates was found more effective than individual application. More disease suppression and vigorous growth patterns of the plants were observed throughout the experiment in seed treatment method. In general, treatments performed better in laboratory experiments than in greenhouse conditions as the controlled conditions favored PGPR growth. The sterilization of soil enabled the PGPR to fight against the specific inoculated organisms where in the field there are larger numbers of organisms that PGPRs have to deal with. The positive relationship between disease incidence and bacterial isolates further confirmed that mixed application of bacteria might have some synergistic effect and support each other for maximum reduction of pathogen in the rhizosphere.

In conclusion, the present results report the potential for using bacterial isolates from rhizosphere of Pakistan as a strategy to suppress pathogens infecting chickpea roots. With the available knowledge, strategies for bacterial application could be optimized to reduce attack of fungal pathogens. This could lead to the development of a handy, economical and environmentally friendly product to combat pathogens infecting roots of chickpeas. Further studies into practical field applications are needed to substantiate our findings [50].

\section{Acknowledgements}

We acknowledge the kind help of Dr. Michael Baum, Director BIGMP, ICARDA Jordan to correct English grammar and quality of the manuscript.

\section{References}

1. Nikam PS, Jagtap GP, Sontakke PL (2007) Management of chickpea wilt caused by Fusarium oxysporum f.sp. ciceris. Afr J Agric Res 2: 692-697. 
Citation: Inam-ul-Haq M, Tahir MI, Hayat R, Khalid R, Ashfaq M, et al. (2015) Bioefficacy of Rhizobacterial Isolates against Root Infecting Fungal Pathogens of Chickpea (Cicer arietinum L.). J Plant Pathol Microbiol S3: 011. doi:10.4172/2157-7471.S3-011

2. Millan T, Clark HJ, Siddique KHM, Buhariwalla HK, Gaur PM, et al. (2006) Chickpea molecular breeding: new tools and concepts. Euphytica 147: 81-103.

3. Dusunceli F, Wood JA, Gupta A, Yadav M, Yadav SS (2007) International trade. Chickpea. In: Yadav SS, Redden R, Chen W, Sharma B (eds) Breeding and management. CAB International. p. 555.

4. FAO (2011) Statistical databases.

5. Canci H, Toker C (2009) Evaluation of annual wild Cicer species for drough and heat resistance under field conditions. Gen Res Crop Evolution 56: 1-6.

6. Toker, Cengiz, Canci H, Yildirim T (2007) Evaluation of perennial wild Cicer species for drought resistance. Gen Res Cr Evol 54: 1781-1786.

7. Jalali BL, Chand H (1992) Chickpea wilt. In: Singh US, Mukhopadhayay AN, Kumar J, Chaube HS (eds) Plant Diseases of International Importance. Prentice Hall, Englewood Cliffs, NJ. pp. 429-444.

8. Tewari AK, Mukhopadhyay AN (2003) Management of chickpea root rot and collar rot by integration of biological and chemical seed treatment. Indian Phytopath 56: 39-42.

9. Wyllie TD (1998) Charcoal rot. In: Sinclair JB, Backman PA (eds) Compendium of soybean diseases, 3rd Edition. APS Press. St. Paul, MN

10. Kamala, Devi SI (2012) Biocontrol properties of indigenous Trichoderma isolates from North-east India against Fusarium oxysporum and Rhizoctonia solani. Af J Biotech 11: 8491-8499.

11. Weller DM (1988) Biological control of soil borne plant pathogens in the rhizosphere with bacteria. Ann Rev of Phytopat 26: 379-407.

12. Kloepper JW (2003) A review of mechanisms for plant growth promotion by PGPR. In: Reddy MS, Anandaraj M, Eapen SJ, Sarma YR, Kleeper JW (eds) Proceedings of the sixth international PGPR workshop. pp. 81-92.

13. Glick BR (1995) The enhancement of plant growth by free living bacteria. Can J Microb 41: 1376-1381.

14. Bender C, Rangaswamy V, Loper J (1999) Polyketide production by plantassociated pseudomonads. Annu Rev Phytopathol 37: 175-196.

15. Hebbar KP, Davey AG, Merrin J, McLoughlins TJ, Dart PJ (1992) Pseudomonas cepacia a potential suppressor of maize soil borne disease: seed inoculation and maize root colonization. Soil Biol Biochem 24: 999-1007.

16. Dwivedi D, Johri BN (2003) Antifungals from fluorescent pseudomonads: Biosynthesis and regulation. Current Science 85: 1693-1703.

17. Siddiqui ZA (2006) PGPR: Prospective biocontrol agents of plant pathogens In: Siddiqui ZA (ed) PGPR: Biocontrol and biofertilization. Springer The Netherlands. pp. 111-142

18. Fridlender M, Inbar J, Chet I (1993) Biological control of soil borne plant pathogens by a b-1,3-gluconase producing Pseudomonas cepacia. Soil Biol Biochem 25: 1211-1221.

19. Ajit NS, Verma R, Shanmugam V (2006) Extracellular chitinases of fluorescen pseudomonads antifungal to Fusarium oxysporum f. sp. dianthi causing carnation wilt. Curr Microbiol 52: 310-316.

20. Validov S, Mavrodi O, De La Fuente L, Boronin A, Weller D, et al. (2005) Antagonistic activity among 2,4-diacetylphloroglucinol-producing fluorescent Pseudomonas spp. FEMS Microbiol Lett 242: 249-256.

21. McSpadden Gardener BB, Schroeder KL, Kalloger SE, Raaijmakers JM Thomashow LS, et al. (2000) Genotypic and phenotypic diversity of phIDcontaining Pseudomonas strains isolated from the rhizosphere of wheat. Appl Environ Microbiol 66: 1939-1946.

22. Pal KK, Tilak KV, Saxena AK, Dey R, Singh CS (2000) Antifungal characteristics of a fluorescent Pseudomonas strain involved in the biological control of Rhizoctonia solani. Microbiol Res 155: 233-242.

23. Liu L, Kloepper JW, Tuzun S (1995) Induction of systemic resistance in cucumber against Fusarium wilt by plant growth promoting rhizobacteria. Phytopath 85: 695-698.

24. Haq MI, Mehmood S, Mujeeb-ur-Rehman H, Ali Z, Tahir MI (2012) Incidence of root rot diseases of soybean in Multan Pakistan and its management by the use of plant growth promoting rhizobacteria. Pak J Bot 44: 2077-2080.

25. Nash SM, Snyder WC (1962) Quantitative estimations by plate counts of propagules of the bean root rot fusarium in field soils. Phytopalh 52: 567-72.
26. Sheikh AH, Ghaffar A (1975) Population study of the sclerotia of Macrophomina phaseolina in cotton fields. Pak J Bot 7: 13-17

27. Barnett HL, Hunter BB (1987) Illustrated Genera of Imperfect Fungi, New York: Macmillan Publishing Company. ISBN 0-02-306395-5.

28. Ali Z, Schumacher HM, Heine-Dobbernack E, El-Banna A, Hafeez FY, et al. (2010) Dicistronic binary vector system-A versatile tool for gene expression studies in cell cultures and plants. J Biotechnol 145: 9-16.

29. Riker AJ, Riker RS (1936) Introduction to research on plant diseases. John's Swift Co. Inc. St. Louis, Chicago, New York, Indianapolis, USA. p.177

30. Sun L, Zhaoxin L, Bie X, Fengxia L, Yang S (2006) Isolation and characterization of a co-producer of fengycins and surfactins, endophytic Bacillus amyloliquefaciens ES-2, from Scutellaria baicalensis Georgi. World J Microbiol Biotechnol 22: 1259-1266.

31. Ali Z, Cousin S, Frühling A, Brambilla E, Schumann P, et al. (2009) Flavobacterium rivuli sp. nov., Flavobacterium subsaxonicum sp. nov. Flavobacterium swingsii sp. nov. and Flavobacterium reichenbachii sp. nov. isolated from a hard water rivulet. Int J Syst Evol Microbiol 59: 2610-2617.

32. Katsivela E, Bonse D, Krüger A, Strömpl C, Livingston A, et al. (1999) An extractive membrane biofilm reactor for degradation of 1,3-dichloropropene in industrial waste water. Appl Microbiol Biotechnol 52: 853-862.

33. Tamura K, Peterson D, Peterson N, Stecher G, Nei M, et al. (2011) MEGA5 molecular evolutionary genetics analysis using maximum likelihood, evolutionary distance, and maximum parsimony methods. Mol Biol Evol 28: 2731-2739.

34. Guo SJ, Geitz G, Franklin T (2004) A comparison of the performance and biological efficiency of new knapsack sprayers and a controlled drople application (CDA) sprayer for the control of the diamondback moth, Plutella xylostella L. (Lepidoptera : Plutellidae). Int J of Pest Manag 50: 121-127.

35. Kloepper JW, Ryu CM, Zhang S (2004) Induced Systemic Resistance and Promotion of Plant Growth by Bacillus spp. Phytopathology 94: 1259-1266.

36. Arrebola E, Jacobs R, Korsten L (2010) Iturin A is the principal inhibitor in the biocontrol activity of Bacillus amyloliquefaciens PPCB004 against postharvest fungal pathogens. J Appl Microbiol 108: 386-395.

37. Chen XH, Koumoutsi A, Scholz R, Borriss R (2009) More than anticipated - production of antibiotics and other secondary metabolites by Bacillus amyloliquefaciens FZB42. J Mol Microbiol Biotechnol 16: 14-24.

38. Joshi R, McSpadden Gardener BB (2006) Identification and Characterization of Novel Genetic Markers Associated with Biological Control Activities in Bacillus subtilis. Phytopathology 96: 145-154.

39. Germinda JJ, Walley FL (1996) Plant growth promoting rhizobacteria alte rooting patterns and arbuscular mycorhizal fungi colonization of field grown spring wheat. Biol Fertil Soils 23: 113-120.

40. Bolton HJ, Elliott LF, Turco RF, Kennedy AC (1990) Rhizosphere colonization of Botrytis cinerea in tomato by Pseudomonas aeruginosa 7NSK2: Role of salicylic, acid, pyochelin and pyocyanin. Mol Plant Microb Inter 15: 147-156.

41. Chandler D, Davidson G, Grant WP, Greaves J, Tatchell GM (2008) Microbial biopesticides for integrated crop management: an assessment of environmental and regulatory sustainability. Trends Food Sci Tech 19: 275-283.

42. Kumar V, Kumar A, Kharwar RN (2007) Antagonistic potential of fluorescent pseudomonads and control of charcoal rot of chickpea caused by Macrophomina phaseolina. J Environ Biol 28: 15-20.

43. Srivastava AK, Singh T, Jana TK, Arora DK (2001) Induced resistance and control of charcoal rot in Cicer arietinum (chickpea) by Pseudomonas fluorescens. Can J Bot 79: 787-795.

44. Akhtar MS, Siddiqui ZA (2009) Use of plant growth-promoting rhizobacteria for the biocontrol of root-rot disease complex of chickpea. Aust Plant Patho 38: $44-50$

45. Jung WJ, An KN, Jin YL, Park RD, Lim KT, Kim KY, Kim TH (2003) Biologica control of damping-off caused by Rhizoctonia solani using chitinase-producing Paenibacillus illinoisensis KJA-424. Soil Biol Biochem 35: 1261-1264.

46. Jung WJ, Yu-Lan J, Young-Cheol K, Kil-Yong K, Ro-Dong P, et al. (2004) Inoculation of Paenibacillus illinoisensis alleviates root mortality, activates of lignification-related enzymes, and induction of the isozymes in pepper plants infected by Phytophthora capsici. Biolog Cont 30: 645-652.

47. Karimi K, Amini J, Harighi B Bahramnejad B (2012) Evaluation of biocontro 
Citation: Inam-ul-Haq M, Tahir MI, Hayat R, Khalid R, Ashfaq M, et al. (2015) Bioefficacy of Rhizobacterial Isolates against Root Infecting Fungal Pathogens of Chickpea (Cicer arietinum L.). J Plant Pathol Microbiol S3: 011. doi:10.4172/2157-7471.S3-011

Page 8 of 8

potential of Pseudomonas and Bacillus spp. against Fusarium wilt of chickpea. Aust J of Crop Sci 6: 695-703.

48. Mishra RK, Prakash O, Alam M, Dikshit A (2010) Influence of Plant Growth Promoting Rhizobacteria (PGPR) on the productivity of Pelargonium graveolens L. Herit. Recent Res in Sci Techn 2: 53-57.
49. Kim OS, Cho YJ, Lee K, Yoon SH, Kim M et al. (2012) Introducing EzTaxon-e: a prokaryotic $16 \mathrm{~S}$ rRNA gene sequence database with phylotypes that represent uncultured species. Int J Syst Evol Microbiol 62: 716-721.

50. Ganesan P, Gnanamnickam SS (1987) Biological control of Sclerotiumr olfsii Sacc.in peanut by inoculation with P. fluoresceins. Soil Biol Biochem 19: 35-38. 